\title{
The Effect of Administrators' Behaviors That Involves Favoritism on Organizational Opposition
}

\author{
Esef Hakan Toytok ${ }^{1}$, Adem Uçar $^{2}$ \\ ${ }^{1}$ Asst.Prof., Siirt University, Faculty of Education, Educational Sciences Department, Turkey \\ ${ }^{2}$ Postgraduate, Siirt University, Faculty of Education, Educational Sciences Department, Turkey \\ Correspondence: Esef Hakan Toytok, Asst.Prof., Siirt University, Faculty of Education, Educational Sciences \\ Department, Turkey.
}

Received: December 3, 2017

doi:10.11114/jets.v6i3a.3160
Accepted: January 31, $2018 \quad$ Online Published: April 1, 2018

URL: https://doi.org/10.11114/jets.v6i3a.3160

\begin{abstract}
Establishment of effective organizations has been the main subject of many researches in recent years. The effectiveness of organizations is directly or indirectly related to many variables. The concepts of favoritism and organizational opposition among these variables aroused the interest of the researcher and in line with the attained sources, it was found out that no researches with regard to these two concepts have been made up until now. We can briefly define favoritism as giving someone priority or granting privilege to someone, favoring someone unjustly and without complying with law and rules, backing someone up; getting away from objectivity and taking side by comparing a certain person, group, opinion or implementation with others when it is required to select one among them. Organizational opposition is defined as uttering about some conflicts and heresy within the organization. The purpose of this research is revealing the impact of favoritism of executives on the organizational opposition. The research made by using descriptive-relational screening model which is one of the quantitative research methods. The universe of research is composed of teachers who were employed in public primary, secondary and high schools in central Siirt (a province in Turkey) in 2015-2016 school year. In the study one of the non-random sampling methods, the convenience sampling method is used. Favoritism Scale (FS) including 15 articles and Organizational Opposition Scale (OOS) which is composed of 7 sub-dimensions and 67 article are used in the research. The obtained data is organized in r. 3.3.1 program (R Core Team, 2016). Confirmatory Factor Analysis (CFA) is made in MPlus 7 program. According to results obtained from research, it is seen that there are significant differences in both organizational opposition and favoritism of executives in terms of gender, the field of study, seniority and school type but there is a significant difference only in organizational opposition with regard to independent variable of union membership. In addition while it is seen that there are positive significant and medium level relationships between favoritism of executives and organizational opposition, it is also found out that favoritism of executives is an important predictor of organizational opposition.
\end{abstract}

Keywords: favoritism, organization, school administrator, opposition, organizational opposition

\section{Introduction}

Mankind is a social being by nature and has been surviving on from past to present day with its habitude of functioning together. This desire to function together necessitated to take common goals and the idea to achieve the common goals effectively made being organized a necessity. Effectively directing the power resulting from being organized towards common goals became a driving force in the emergence of the phenomenon of governance. Today organizations are as powerful as the yare effective. It is a known fact that the effectiveness of an organization can not be obtained by only technological resources (Epcacan \& Pesen, 2017). Therefore the establishment of effective organizations became the primary concern of many researches recently. Researches conducted show that effectiveness of organizations is in a direct or indirect relationship with numerous variables. One of these variables is named as "favoritism of executives". The phenomenon of favoritism is also named as "SpoilSytem" in English. When definitions of favoritism are examined, favoritism is colloquially known as "friend at court" and in respect of etymology, it is seen that this phrase is used as synonymous with "favoritism" (Cinar, 2009; Palani and sweaters, 2014; Aktan 2001). But Kayabaşı (2005) defines it in his research as a type corruption in public bureaucracy and political decision-making process. Unfortunately favoritism is seen in many fields today both in public and private sector institutions in the form of favoring kith and kin, political 
followers and union members. Rights, positions and titles unrightly gained due to favoritism would cause nonrecoverable negativity in an organization. In order to avoid this negativity, some organizations determine appropriate norms within themselves to prevent favoritism. For example some private institutions don't employ kith and kin and relatives of their employees or they employ them in different departments (Grensing-Pophal, 2007). Whereas there are universal ethical values that national or international organizations should adopt (Gültekin, 2015). Organizations should execute employment, promotion or awarding and dismissal in compliance with these values. Conducted national and international researches show that favoritism has various forms depending on the favored person. These are collected under six titles as "favoritism (favoring relatives)", "Cronyism (favoring kith and kin)", "Partisanship (political favoritism)", "Patronage (service favoritism) and "Gender Bias" (Kawanaka, 2007; Khanthi and Tsang, 2003; Loewe et al., 2007; Sheridan, 2007; Samuels, 2002; Denemark, 2000; Kurt and Doğramac1, 2014; Polat and Kazak, 2014; Erdem, Çeribaş and Karabaş, 2013; Meriç, 2012; Erdem and Meriç, 2013; Meriç and Erdem, 2012; Büte, 2011; Erdem, 2010; Aktan, 2001; Aydoğan, 2009).

It is seen that another prominent concept of recent years which affects organizational effectiveness is "organizational opposition". The concept of organizational opposition defines the situation when there is a difference of opinion between the members of organization and senior management of organization due to some behaviors, events and circumstances. In order for this situation to be called opposition, the difference should be openly mentioned. (Kassing and DiCioccio, 2004; Kassing, 1998; Kassing, 1997a; Özdemir, 2010). This difference of opinion can be experienced with members of the organization as well as with the management. Kassing and Armstrong attributed opposing behaviors of members of the organization to two main factors in their researches they conducted in 2002 and 2009. One of these factors is unjust behaviors of organizational management towards members of the organization and violating their rights. The second triggering factor is explained as systematic, hostile and unethical "bullying" behaviors of a member or a group in the workplace The bullying occurring in workplaces are behaviors such as threatening, intimidation, isolation, bringing into disrepute and looking down on work performance (Fox and Stallworth, 2009). There are four types of opposing behaviors seen among the members of an organization. These are whistleblowing among members, clearly stated opposition, horizontal opposition and replacement (Ağaldağ, 2013; Kassing, J. W.,Piemonte, N. M., Goman, C. C., Mitchell, C. A., 2012; Kassing, 2008; Kassing, 1997b).

As mentioned above, living together and need to be managed shall remain as an inevitable reality as long as mankind exists. The forms of management created by mankind shall never be free from problems and favoritism shall be inevitable whether less or more. Such negative behaviors in organizations would not be always accepted by their members. In organizational structures where the values like fairness, rightfulness and conscience are violated and where favoritism are common, members of the organization would tend to defend the values they believe in and form a basis for the emergence of organizational opposition. Defined as a social open system, schools are regarded as organizations. If actions and operations in the organizational structure of schools are against ethical values and laws, the negative impact on the attitudes of school employees towards their school would naturally be an inevitable result.

In terms of perceptions of teachers, the purpose of this research is finding answers to below questions:

1. What is the level of favoritism presented by school management?

2. What is the perception level of organizational opposition at schools?

3. To what extent do the favoritism of management predict organizational opposition?

\section{Method}

As the research intends to explain the relationship between the favoritism of school management and organizational opposition, it is a study conducted by using descriptive relational screening model. In researches conducted in compliance with descriptive-relational screening model, a situation or event is described as is and relationships, impact and levels of the variables causing this situation or event are determined (Kaya, Balay and Göçen, 2012).

The universe of this research is composed of 2083 teachers employed in 53 different schools in the center of Siirt Province in 2015-2016 school year. The accessibility of school structures in the center of Siirt is taken into consideration in the research and Convenience Sampling method, which is one of the non-random sampling methods is used. Non-random sampling is a sampling method in which a sampling is composed by beginning from the most accessible one till having a group as big as the researcher needs (Büyüköztürk, 2014:90). Opinions of 677 teachers that have the capacity to reflect the universe are included in the research. In a universe of 2083 respondents, 322 different opinionsseem sufficient in a 95\% confidence interval (for $p<.05)$ (Can, 2014). Information about the sampling is shown in Table 1. 
Table 1. Information on sampling

\begin{tabular}{lll}
\hline Demographic Characters (N =677) & $\mathrm{N}$ & $\%$ \\
\hline $\begin{array}{l}\text { Gender } \\
\text { Female }\end{array}$ & 255 & 37.7 \\
$\quad$ Male & 422 & 62.3 \\
Seniority & & \\
$\quad$ 1-5 Years & 219 & 32.3 \\
6-10 Years & 206 & 30.4 \\
11-15 Years & 157 & 23.2 \\
$\quad$ 16-20 Years & 57 & 8.4 \\
21 Years and above & 38 & 5.6 \\
Field of Study & & \\
$\quad$ Class Teacher & 316 & 46.7 \\
$\quad$ Branch Teacher & 361 & 53.3 \\
Are You a Member of a Union? & & \\
$\quad$ Yes & 372 & 54.9 \\
$\quad$ No & 305 & 45.1 \\
Type of School & & \\
$\quad$ Primary school & \\
$\quad$ Middle School & 346 & 51.1 \\
$\quad$ High School & 201 & 29.7 \\
$\quad$ Total & 130 & 19.2 \\
\hline
\end{tabular}

As data collection tools the "Organizational Opposition Scale (OOS)" with 67 articles and three sub-dimensions which was developed by Özdemir (2010) and "Favoritism of School Management Scale (FS)" developed by Aydoğan (2009) with 15 articles are used in this research.

As the result of reliability analysis made for OOS, the values of Raykov's coefficient rho $(\rho)$ statistics are calculated as follows; in dimension of reasons leading to organizational opposition $\rho=.988$; in dimension of opposing behavior types $\rho=.955$; in dimension of opposition results"in terms of teacher" $\rho=.983$, "in terms of administrator" $\rho=.978$, and "in terms of school" $\rho=.979$. As the result of reliability analysis made for NAS, the values of Raykov's coefficient rho statistics is found as $\rho=.988$. If Raykov's "factor rho coefficient" statistics $(1997,2004)$ valuesare equal to or greater .70, then it is reliable. In order to confirm the validity of research Confirmatory Factor Analysis (CFA) is made for both scales and it is seen that all factor loads are high and positive. Also the values of Fit Statistics (FIT) obtained to confirm the validity of research are presented in Table 2.

Table 2. Fit statistics (FIT) values

\begin{tabular}{|c|c|c|c|c|c|c|c|}
\hline $\begin{array}{l}\text { Summary of Confirmatory } \\
\text { Factor Analysis Statistics Model } \\
(\mathrm{N}=677)\end{array}$ & $\chi^{2}$ & Df & $\mathrm{p}$ & $\begin{array}{l}\text { RMSEA } \\
(90 \% \mathrm{CI})\end{array}$ & CFI & TLI & SRMR \\
\hline $\begin{array}{l}\text { Causes of Organizational } \\
\text { Opposition }\end{array}$ & 4473.68 & 252 & $<.0001$ & $\begin{array}{l}0.16 \\
(0.153,0.161)\end{array}$ & 0.96 & 0.95 & 0.08 \\
\hline Types of Opposing Behaviors & 2547.11 & 116 & $<.0001$ & $\begin{array}{l}0.18 \\
(0.170,0.182)\end{array}$ & 0.94 & 0.93 & 0.09 \\
\hline $\begin{array}{l}\text { Results of Opposition, "In } \\
\text { Terms of Teachers" }\end{array}$ & 1385.74 & 54 & $<.0001$ & $\begin{array}{l}0.19 \\
(0.182,0.200)\end{array}$ & 0.98 & 0.98 & 0.05 \\
\hline $\begin{array}{l}\text { Results of Opposition, "In } \\
\text { Terms of Administrator" }\end{array}$ & 655.55 & 14 & $<.0001$ & $\begin{array}{l}0.26 \\
(0.244,0.278)\end{array}$ & 0.99 & 0.98 & 0.05 \\
\hline $\begin{array}{l}\text { Results of Opposition, "In } \\
\text { Terms of School" }\end{array}$ & 848.32 & 21 & $<.0001$ & $\begin{array}{l}0.30 \\
(0.280,0.314)\end{array}$ & 0.99 & 0.98 & 0.05 \\
\hline Favoritism & 1734.38 & 90 & $<.0001$ & $\begin{array}{l}0.16 \\
(0.158,0.171)\end{array}$ & 0.98 & 0.98 & 0.03 \\
\hline
\end{tabular}

When Table 2 is examined Comparative Fit Index (CFI) value in all variables is.94 and above; Tucker-Lewis index (TLI) value is .93 and above and this shows us there is a good fit (FIT). According to Hu and Bentler (1999), CFI and TLI values can be accepted within the range of.90 and.95.if it is equal to or greater than .95 , then it is accepted as a good 
modelling index. According to Browne and Cudeck (1993), if RMSEA valueis equal to or less than .050, then fit increases that much. But RMSEA values obtained in our research don't meet this range. But RMSEA is a statistics based on a multivariate normality variable (Kline, 2011). Since the variables subjecting this research are composed of data collected pursuant to sorting scale, it reveals that the unfitting values obtained as the result of RMSEA analysis don't mean that the fit analysis is not valid. In addition SRMR values of each variable being equal to or less than .09shows us that the research has a good model fit according to statistical results.

\section{Findings}

3.1 Findings Related to the Question of "What Is the Level of Favoritism of School Management? Predict Organizational Opposition?

Findings of the research indicate that the arithmetic mean of favoritism of school management is $(\bar{X}=2.31)$ and standard deviation is (S.s.=1.19). It is seen that this mean corresponds to the perception of "I don't agree" in range value scale. This value reveals that the teachers working in Siirt province don't believe that school management does not behave in a favoritist way among teachers for various reasons. It is considered by teachers that favoritism of school managers are mostly seen during inspections and plan examinations and the possibility of teachers' giving additional courses in other schools.

Findings related to the question of "What is the Perception Level of Predict Organizational Opposition?

Findings of the research are presented in Table 3.

Table 3. Arithmetic mean and standard deviation values regarding sub-dimensions of organizational opposition

\begin{tabular}{lll}
\hline & $\bar{X}$ & S.d. \\
\hline Reasonsfor Organizational Opposition & 2.55 & 1.17 \\
Oppositional Behavior: Implicit Opposition & 2.60 & 1.18 \\
Oppositional Behavior: Whistleblowing & 2.12 & 1.04 \\
Oppositional Behavior: Explicit Opposition & 3.19 & 1.21 \\
The Results of The Opposition in Terms of The & 2.34 & 1.13 \\
The Results of The Opposition in Terms of The & 2.03 & 1.04 \\
The Results of The Opposition in Terms of The School & 3.18 & 1.26 \\
\hline
\end{tabular}

When findings in Table 3 are examined, it is seen that teachers perceive highest organizational opposition in the dimension of results for the school ( $X=3.18$ ) and lowest perception is in the dimension of the results of opposition for manager ( $X=2.03$ ). When answers given to OOS are examined, the highest mean value is obtained in the answer of "They try to make me accept their political view to me" (Reasons of Opposition: Article 21) ( $X=3.05$ ) and the lowest mean value is obtained in the answer of "They actually harass me" (Reasons of Opposition: Article 24) ( $X=2.02)$.

Findings related to the question of "To What Extent does the Favoritism of Management Predict Organizational Opposition?

One way simple regression results of participating teachers related to the prediction on the level of reasons causing organizational opposition due to favoritism of managers are presented in Table 4.

Table 4. Results of the analysis related to predictive reasons for organizational opposition by favoritism

\begin{tabular}{lllll}
\hline \multicolumn{5}{l}{$\begin{array}{l}\text { Predictive Variable } \\
\text { (Reasons for Organizational Opposition) }\end{array}$} \\
\hline B & $\mathrm{S}$ & $\mathrm{t}$ & $\mathrm{p}$ \\
Constant & -0.01 & 0.03 & -0.20 & .8390 \\
Favoritism Behaviors & 0.54 & 0.03 & 16.93 & $<0.0001^{* * *}$ \\
\hline$R^{2}=.30$ & & $\mathrm{r}=.545$ & & \\
$R_{\text {Adj. }}^{2}=.30$ & & $\mathrm{~F}(1,675)=286.70$ & $\mathrm{p}<0.0001$ & \\
\hline
\end{tabular}

Not: $* \mathrm{p}<.05, * * \mathrm{p}<.01, * * * \mathrm{p}<.001$

According to findings in Table 4, there is a medium level and positive significant relation between favoritismand organizational opposition ( $\mathrm{r}=.545)$. Moreover the one-point increase in favoritism is related to 0.54-point increase on 
the level of reasons of organizational opposition ( $\mathrm{p}<.0001)$. This value shows us that $30 \%$ of the reasons of the dependent variable of organizational opposition are predicted by the independent variable of favoritism $\left(R^{2}=.30\right)$.

The one way simple regression results with regard to how the teachers participating the research perceive the favoritism of managers predict the implicit opposition level, an organizational behavior pattern are presented in Table 5.

Table 5. Results of the analysis related to predictive reasons for implicit opposition, an organizational opposition pattern by favoritism

\begin{tabular}{|c|c|c|c|c|}
\hline & \multicolumn{4}{|c|}{$\begin{array}{l}\text { Predictive Variable } \\
\text { (Implicit Opposition) }\end{array}$} \\
\hline & B & $\mathrm{S}$ & $\mathrm{t}$ & $\mathrm{p}$ \\
\hline Constant & 0.01 & 0.03 & 0.47 & .6380 \\
\hline Favoritism Behaviors & 0.60 & 0.03 & 19.49 & $<0.0001 * * *$ \\
\hline$R^{2}=.36$ & & $\mathrm{r}=0.599$ & & \\
\hline$R_{A d j .}^{2}=.36$ & & $F(1,675)=379.80$ & $\mathrm{p}<0.0001$ & \\
\hline
\end{tabular}

Not: $* \mathrm{p}<.05, * * \mathrm{p}<.01, * * * \mathrm{p}<.001$

According to findings presented in Table 5, there is a medium level and positive significant relationship between favoritismand implicit opposition, an organizational opposition $(\mathrm{r}=.599)$. One-point increase in favoritism is related to 0.60 -point increase on the level of implicit opposition ( $p<.0001$ ). This value shows us that $36 \%$ of the dependent variable of implicit opposition is predicted by the independent variable of favoritism. $\left(R^{2}=.36\right)$.

Table 6. Results of the analysis related to prediction of whistleblowing, one of the organizational opposition patterns by favoritism

\begin{tabular}{lllll}
\hline \multicolumn{5}{l}{ Predictive Variable (Whistleblowing) } \\
\hline & $\mathrm{B}$ & $\mathrm{S}$ & $\mathrm{t}$ & $\mathrm{p}$ \\
Constant & 0.03 & 0.03 & 1.01 & .2770 \\
$\begin{array}{l}\text { Favoritism } \\
\text { Behaviors }\end{array}$ & 0.43 & 0.03 & 14.28 & $<0.0001^{* * * *}$ \\
\hline $\begin{array}{l}R^{2}=.23 \\
R_{A d j .}^{2}=.23\end{array}$ & & $\mathrm{r}=0.479$ & & \\
\hline
\end{tabular}

Not: $* \mathrm{p}<.05, * * \mathrm{p}<.01, * * * \mathrm{p}<.001$

According to findings presented in Table 6 , there is a medium level and positive significant relationship between favoritism and whistleblowing, an organizational behavior pattern $(r=.(r=.479)$. One-point increase in favoritism is related to 0.43 -point increase on the level of whistleblowing ( $\mathrm{p}<.0001)$. This value shows us that $23 \%$ of the dependent variable of implicit opposition is predicted by the independent variable of favoritism $\left(R^{2}=.23\right)$.

Table 7. Results of the analysis related to prediction of explicit opposition, one of the organizational opposition patterns by favoritism

\begin{tabular}{lllll}
\hline \multicolumn{5}{c}{$\begin{array}{l}\text { Predictive Variable } \\
\text { (Explicit Opposition) }\end{array}$} \\
\hline & $\mathrm{B}$ & $\mathrm{S}$ & $\mathrm{t}$ & $\mathrm{p}$ \\
Constant & -0.01 & 0.03 & -0.51 & .6130 \\
Favoritism Behaviors & 0.50 & 0.03 & 16.14 & $<0.0001^{* * *}$ \\
\hline $\boldsymbol{R}^{2}=.28$ & & $\mathrm{r}=0.526$ & & \\
$\boldsymbol{R}_{\text {Adj. }}^{2}=.28$ & & $\mathrm{~F}(1,675)=260.40$ & $\mathrm{p}<0.0001$ & \\
\hline
\end{tabular}

Not: $* \mathrm{p}<.05, * * \mathrm{p}<.01, * * * \mathrm{p}<.001$

According to findings presented in Table 7, there is a medium level and positive significant relationship between favoritism and explicit opposition, an organizational opposition pattern $(\mathrm{r}=.526)$. One-point increase in favoritism is related to 0.60-point increase on the level of explicit opposition $(\mathrm{p}<.0001)$. This value shows us that $28 \%$ of the 
dependent variable of explicit opposition is predicted by the independent variable of favoritism. $\left(R^{2}=.28\right)$.

Table 8. Results of the analysis related to prediction of organizational opposition by favoritism in terms of teachers

Predictive Variable

(The Results of The Opposition in Terms of The Teacher)

\begin{tabular}{lllll}
\hline & $\mathrm{B}$ & $\mathrm{S}$ & $\mathrm{t}$ & $\mathrm{p}$ \\
Constant & 0.00 & 0.03 & -0.13 & .895 \\
Favoritism Behaviors & 0.66 & 0.03 & 23.33 & $<0.0001 * * *$ \\
\hline $\boldsymbol{R}^{2}=.45$ & & $\mathrm{r}=0.667$ & & \\
$\boldsymbol{R}_{\text {Adj. }}^{2}=.45$ & & $\mathrm{~F}(1,675)=544.40$ & $\mathrm{p}<0.0001$ & \\
\hline
\end{tabular}

Not: $* \mathrm{p}<.05, * * \mathrm{p}<.01, * * * \mathrm{p}<.001$

According to findings presented in Table 8 , there is a medium level and positive significant relationship between favoritism and results of opposition in terms of teachers $(r=.667)$. One-point increase in favoritism is related to 0.66-point increase on the level of results of organizational opposition in terms of teachers ( $\mathrm{p}<.0001)$. This value shows us that $45 \%$ of the dependent variable of the results of organizational opposition in terms of teachers is predicted by the independent variable of favoritism. $\left(R^{2}=.45\right)$.

Table 9. Results of the analysis related to prediction of organizational opposition by favoritism in terms of managers

\begin{tabular}{lllll}
\hline \multicolumn{5}{c}{$\begin{array}{l}\text { Predictive Variable } \\
\text { (The Results of The Opposition in Terms of The } \\
\text { Manager) }\end{array}$} \\
\hline B & $\mathrm{S}$ & $\mathrm{t}$ & $\mathrm{p}$ \\
Constant & 0.04 & 0.03 & 1.19 & .2330 \\
Favoritism Behaviors & 0.39 & 0.03 & 12.03 & $<0.0001 * * *$ \\
\hline$R^{2}=.17$ & & $\mathrm{r}=0.418$ & \\
$R_{\text {Adj. }}^{2}=.17$ & $\mathrm{~F}(1,675)=144.80$ & $\mathrm{p}<0.0001$ & \\
\hline
\end{tabular}

Not: $* \mathrm{p}<.05, * * \mathrm{p}<.01, * * * \mathrm{p}<.001$

According to findings presented in Table 9, there is a medium level and positive significant relationship between favoritism and results of opposition in terms of managers $(r=.418)$. One-point increase in favoritism is related to 0.66 -point increase on the level of results of organizational opposition in terms of managers $(p<.0001)$. This value shows us that $17 \%$ of the dependent variable of the results of organizational opposition in terms of managers is predicted by the independent variable of favoritism. $\left(R^{2}=.17\right)$.

Table 10. Results of the analysis related to prediction of organizational opposition by favoritism in terms of school

\begin{tabular}{lllcc}
\hline \multicolumn{5}{c}{$\begin{array}{c}\text { Predictive Variable } \\
\text { (The Results of The Opposition in Terms of The School) }\end{array}$} \\
\hline B & $\mathrm{S}$ & $\mathrm{t}$ & $\mathrm{p}$ \\
Constant & 0.00 & 0.03 & -0.25 & .805 \\
Favoritism Behaviors & 0.38 & 0.03 & 11.08 & $<0.0001 * * *$ \\
\hline$R^{2}=.15$ & & $\mathrm{r}=0.390$ & & \\
$R_{\text {Adj. }}^{2}=.15$ & & $\mathrm{~F}(1,675)=122.80$ & $\mathrm{p}<0.0001$ & \\
\hline
\end{tabular}

Not: $* \mathrm{p}<.05, * * \mathrm{p}<.01, * * * \mathrm{p}<.001$

According to findings presented in Table 10, there is a medium level and positive significant relationship between favoritism and results of opposition in terms of school( $\mathrm{r}=.390)$. One-point increase in favoritism is related to 0.38 -point increase on the level of results of organizational opposition in terms of school(p<.0001). This value shows us that $15 \%$ of the dependent variable of the results of organizational opposition in terms of school is predicted by the independent variable of favoritism. $\left(R^{2}=.15\right)$. 


\section{Discussion}

The results obtained from the research indicate that the school managers working at schools in central Siirt don't completely avoid favoritism and favoritism is especially increasing more in matters like inspection, auditing, promotion and connivance. It is observed that this perception is higher among male teachers than female teachers. This may be attributed to the fact that male teachers have more expectations from their schools and they are more familiar to works and operations in the schools and thus they can make observations and criticize when they see fit. As a matter of fact, it is seen that similar results about male teachers have been obtained in studies of Turan (2016), Düz (2012), Meriç (2012), Aydoğan (2009) and Jones (2013). According to other findings of the research, classroom teachers believe in comparison to branch teachers that managers exhibit favoritism more. When the source of this perception is examined, it might be suggested that classroom teachers spend more time at school and they are exposed to behaviors of managers more than others.

When the findings of the research regarding organizational opposition are examined, it is seen that male teachers perceive organizational opposition at a higher level than female teachers, same as in their perception of favoritism. In addition it is assumed that when opposing behaviors of male teachers against managers at schools are more than the same behaviors of female teachers would be more beneficial with regard to developments at school. Miceli and Near, (2006); Sims and Keenan, (1998); Ağalday (2013); Özdemir (2010) presents similar results in their researches. Contrary to research findings, Zhuang (2002) claims in his research that females oppose in organizations more than males.

It is determined in the study that there are medium level and positive relationships between favoritism and various organizational opposition patterns like implicit opposition, whistleblowing, explicit opposition, results of opposition in terms of teachers, results of opposition in terms of management and results of opposition in terms of schools. Distinctly from the investigation on the dimension of implicit opposition in the research (Kassing, 1997a, 1998; Kassing and Avtgis, 2009; Garner; 2009; Evans, 2007 and Özdemir, 2010) that members of the organization don't exhibit explicit opposition against managers as they abstain from negative results they would face with. It was determined in the research that the perception of teachers regarding implicit opposition is at medium level and that organization members who don't explicitly or directly oppose prefer either staying silent or sharing the situation with their kith and kin, friends or persons who are not members of the organization with regard to attitudes and behaviors that they don't internalize.

Findings obtained from the research show that favoritism of managers are not accepted by teachers and they could exhibit opposing behaviors pertinent to their internal and external natures. People perform various risk analyses regarding pros and cons of an opposing behavior before they act. They will assess the consequences of the opposing behavior they will develop on the basis of their inherent risk analyses. Teachers might prefer implicit opposition instead of explicit one towards future benefits and substitutions they would obtain in future at institutions they work. On the other hand, when school manager is open to criticism, places emphasis on democratic values and has a good communication with teachers, then teachers can express their opinions more explicitly Some teachers believe that expressing the problems in their institutions in their work environment would not solve them and thus they endeavor to seek for solutions by conveying the problems to stakeholders outside the institution.

Opposing behaviors of teachers might have consequences in terms of teachers themselves, manager and school. According to the results obtained from the research, teachers know that when they show opposing behaviors the management might look for their deficiency, threaten them and give them problems with regard to their curriculum. However it is also understood that they believe their opposing behaviors in spite of these consequences that would affect themselves, would lessen the support of school management, the manager would be isolated and lose their power at school. Finally, it has been seen that the teachers believe their school environment would be democratized more and improved and self-control skills of teachers would increase due to their opposing behaviors at their schools. Thus teachers believe the unethical and unlawful treatments at their schools would be reduced as much as possible.

\section{Conclusion}

According to the results obtained in the research, it is seen that teachers working in central Siirt believe the school managers exhibit favoritism in some applications like assignments, rewards, additional classes and favoritism especially increases when it comes to townsman and kin and relatives. Teachers think that favoritism of school management mostly affects schools and operational process in a negative way. When the results of organizational opposition which is the other variable of research are examined, teachers stated that they exhibit organizational opposition at their school from time to time. It is seen that the main behaviors causing organizational opposition are the management's decision-making process without participation of teachers. They stated that this situation affects the schools at most as it was seen in favoritism and the manager is affected by it the least. 
According to other results obtained in the research there is a medium level, positive and significant relationship between favoritism of school management and causes of organizational opposition, behavioral patterns and results. In addition it is found out that favoritism of managers predicts organizational opposition to a great extent. When predictor variables are examined, it is seen that the highest level (almost 50\%) is seen in terms of the consequences of organizational opposition for teachers while the lowest level is associated with the consequences of organizational opposition for school. Accordingly, organizational opposition at schools increases as favoritism of management does.

Consequently, in order for the schools to achieve the requested standard in terms of organizational objectives, they should have effective organizational structures. As the behaviors of school management is an important determinant for the schools to have effective structures, school management should avoid favoritism. Therefore managers should shape their management process by basing on universal values like transparency, accountability, participatory decision making and merit and avoid bullying, violation of rights, political or denominational partisanship. Organizations would be more dynamic and effective only by this means. On the other hand, managers should not be afraid of organizational opposition. Because the opposition in an organization proves the availability of different says and different says would be the indicator of the democratic approach in the said organization. If the manager makes decisions and behaves as we have mentioned above, the organizational opposition in the organization would provide a different perspective to managers and thus, facilitate their job.

\section{Recommendations}

Policy makers of the Ministry of National Education should develop open legislation based on current standards to prevent favoritism in order to make schools more effective and productive and constitute local and national central control mechanisms to supervise these implementations and attach importance to the principle of accountability and transparency. In addition the same research could be repeated in different provinces and regions so that the results would be compared.

\section{References}

Ağalday, B. (2013), Opinion of Teachers Stationed at Elementary Schools Regarding Organizational Opposition (Example of Mardin Province). (Post Graduate Thesis) Diyarbakır: Dicle University, Institute Of Educational Sciences.

Aktan, C. C. (2001). Political Ethics and Political Corruption, Coşkun Can Aktan (Ed.), Anti-corruption strategies. Ankara: Hak-İş Publications, 51-69.

Aydogan, I. (2009). Favoritism in the Turkish Educational System: Nepotism, Cronyism and Patronage. Online Submission, 4 (1).Bakırc1, K. (2000). Sexual Harassment at Workplace and Solution Proposals Regarding Turkish Business Law. Access Date: 01/08/2016. http://www.kamu-is.org.tr/pdf/5325.pdf.

Browne, M. W., \& Cudeck, R. (1993). Alternative ways of assesing model fit. In K.A. Bollen\& J.S. Long (Eds.), Testing structural equation models (pp. 136-162). Newbury Park, CA: Sage

Büte, M. (2011). Effects of Favoritism on Employees and Relationship with Application of Human Resources: A Research Towards Turkish Public Banks. Ataturk University Institute of Social Sciences Journal, 15(1), 189-195.

Büyüköztürk, Ş. (2014). Scientific Research Methods. Ankara: Pegem Akademi.

Can, A. (2014). Quantitative Data Analysis During Scientific Research Process with SPSS. Ankara: Pegem Publications.

Çınar, İ. (2009). Favoritism and Corruption: A Conceptual Analysis Study Eğitişim Magazine, 24.

Denemark, D. (2000). Partisan pork barel in parliamentary systems: Australian pork barrel constituency level grants. The Journial of Politics. 62(2). https://doi.org/10.1111/0022-3816.00039

Düz, S. (2012). Examination of the Relationship Between Nepotism and Organizational Commitment at Accommodation Facilities (Post Graduate Thesis) Afyon: Kocatepe University Institute of Social Sciences.

Erdem, B., Çeribaş, S., \& Karataş, A. (2013). Perceptions of Cronyism by Employees at Hotel Establishments: A Research Made at One-star, Two-star and Three-star Hotels in İstanbul. Çukurova Üniversitesi IIBF Magazine. 17(1), 51-69.

Erdem, M. (2010). Quality of Professional Life and Relationship with Organizational Commitment at High Schools With Regard to Perceptions of Teachers. Education Method in Theory and Practice. 16(4), 511-536.

Erdem, M., \& Meriç, E. (2013). Favoritism of School Management With Regard to Perceptions of Teachers Working at Elementary Schools. Education Method in Theory and Practice, 19(3), 467-498.

Evans, J. D. (1996). Straightforward Statistics For The Behavioral Sciences. Pacific Grove, CA: Brooks/Cole 
Publishing.

Fox, S., \& Stallworth, L. E. (2009). Building a framework for two internal organizational approache store solving and preventing work place bullying: alternatıve dispute resolution and training. Consulting Psychology Journal: Practiceand Research, 61(3), 220-241. https://doi.org/10.1037/a0016637

Garner, J. T. (2009). Strategic dissent: expressions of organizational dissent motivated by influence goals. International Journal of Strategic Management, 3, 34-51. https://doi.org/10.1080/15531180802606471

Grensing-Pophal, L. (2007). All in the Family. HR magazine, September, 66-70.

Gültekin, S. (2015). A Research on Ethical Management, Corruption and Poverty. International Journal of Economic and Administrative Studie, 7(14). 399-421.

Hu, L., \& Bentler, P. M. (1999). Cutoffcriteriafor fit indexes in covariance structure analysis: Conventional criteriaversus new alternatives. Structural Equation Modeling, 6(1), 1-55. https://doi.org/10.1080/10705519909540118

Jones, R. G. (Ed.). (2013). Nepotism in Organizations. Routledge.

Kassing, J. W. (1997a). Articulating, antagonizing, and displacing: a model of employeed is sent. Communication Studies, 48, 311-332. https://doi.org/10.1080/10510979709368510

Kassing, J. W. (1997b). Development and Validation of the Organizational Dissent Scale. Doktora Tezi), Ohio: Kent State University.

Kassing, J. W. (1998). Development and validation of the organizational dissent scale. Management Communication Quarterly, 12(2), 183-229. https://doi.org/10.1177/0893318998122002

Kassing, J. W. (2008). Considerthis: a comparison of factors contributing to employees' expressions of dissent. Communication Quarterly, 56, 342-355. https://doi.org/10.1080/01463370802240825

Kassing, J. W., \& Armstrong, T. A. (2002). Someone's going to hear about this; examining the association between dissent-triggerin gevents and employees' dissent expression. Management Communication Quarterly, 16(1), 39-65. https://doi.org/10.1177/0893318902161002

Kassing, J. W., \& Armstrong, T. A. (2009). Examining the association of job tenure, employment history, and organizational status with employeedissent. Communication Research Reports, 18, $264-273$. https://doi.org/10.1080/08824090109384806

Kassing, J. W., \& DiCioccio, R. L. (2004). Testing a work place experience explanation of displaced dissent. Communication Reports, 17, 111-120. https://doi.org/10.1080/08934210409389380

Kassing, J. W., \& Avtgis, T. A. (2009). Dissension in the organization as a function of control expectancies. Communication Research Reports.18, 118. https://doi.org/10.1080/08824090109384789

Kassing, J. W., Piemonte, N. M., Goman, C. C., \& Mitchell, C. A. (2012). Dissent expression as an indicator of work engagement and intention to leave. Journal of Business Communication, 49(3). 237-253. https://doi.org/10.1177/0021943612446751

Kawanaka, T. (2007). Who eats the most?: quantitative analysis of pork barrel distributions in the philippines. Erişim Tarihi: 05.08.2016 http://hdl. handle.net/2344/633.

Kayabaş1, Y. (2005). Constitutional Economics as a Solution to Political Corruption. (Unpublished Master Thesis), Adana: Çukurova University Institute of Social Sciences.

Khantri, N., \& Tsang, E. W. (2003). An tecedents and consequences of cronyism in organizations. Journal of Business Ethics, 43(4), 289-303. https://doi.org/10.1023/A:1023081629529

Kline, R. B. (2011). Principles And Practice of Structural Equation Modeling (Third Edition). New York: The Guilford Press

Kurt, E., \& Doğramac1, B. (2014). Measurement of Favoritism Perception on Dimensions of Promotion, Operational Nepotism and Employment: A Research on the Employees of a Municipal Subsidiary in İstanbul. Elektronik Mesleki Gelişim ve Araştırma Magazine (EJOIR), 2, 82-87.

Loewe, M., Blume, J., Schönleber, V., Seibert, S., Speer, J., \& Voss, C. (2007). The impact of favouritism on the business climate: A study on wasta in Jordan. Available at SSRN 2218821, 30-197. https://doi.org/10.2139/ssrn.2218821

Meriç, E. (2012). Favoritism of School Management With Regard to Perceptions of Teachers Working at Elementary 
Schools. (Master's Thesis), Van: Yüzüncü Y1l University Institute of Educational Sciences.

Meriç, E. (2012). Favoritism of School Management With Regard to Perceptions of Teachers Working at Elementary Schools. (Master's Thesis), Van: Yüzüncü Y1l University Institute of Educational Sciences.

Meriç, E.. \& Erdem, M. (2012). A Scale Development Study on Favoritism at School Management. Eğitim Bilimleri Araştırma Dergisi EBAD-JERS, 2(2), 141-154.

Miceli, M. P., \&Near, J. P. (1985). Characteristics of organizational climate and perceived wrong doing associated with whistleblowing decisions. Personnel Psychology, 38(3), 525-544. https://doi.org/10.1111/j.1744-6570.1985.tb00558.x

Özdemir, M. (2010). Opinions of Managers and Teachers Working at Public General High Schools in Ankara Province Regarding Organisational Opposition (Doctoral Thesis). Ankara: Ankara University, Institute of Educational Sciences.

Polat, E., \& Kazak, S. (2014). Relationship Between Favoritism of School Managers and Conception of Organisational Fairness of Teachers. Kuram ve uygulamada eğitim yönetimi dergisi, 20(1).

Raykov, T. (1997). Estimation of composite reliability for congeneric measures. Applied Psychological Measurement, 21(2), 173-184. https://doi.org/10.1177/01466216970212006

Raykov, T. (2004). Point and Interval Estimation of Reliability for Multiple-Component Measuring Instruments via Linear Constraint Covariance Structure Modeling. Structure Equation Modeling, 11, 342-356. https://doi.org/10.1207/s15328007sem1103_3

Samuels, D. J. (2012). Porkbarreling is not credit claiming or advertising: campaign finance and the sources of the personal vote in brazil. The Journual of Politics, 64(3), 846-863. Erişim Tarihi: 05/08/2016. http://www.polisci.umn.edu/ dsamuels/Samuels\%20JOP02.pdf

Sheridan, M. K. (2007). Just because it's sex doesn't mean it's because of sex: the need for new legislation to target $\begin{array}{llllll}\text { sexual favoritism. } & 40(3), & 279-423 . & \text { Erişim } & \text { Tarihi: } & \text { 08.08.2016 }\end{array}$ http://www.columbia.edu/cu/jlsp/pdf/Spring2007/Sheridan.pdf

Sims, R. L., \& Keenan, J. P. (1998). Predictors of external whistleblowing: organizational and intrapersonal variables. Journal of Business Ethics, 17, 411-421. https://doi.org/10.1023/A:1005763807868

Turan, R. (2016). Analysis of Nepotism, Cronyism and Patronage Trends in the Context of Perception of Institutionalization. (Master's Thesis), Izmir: Ege University, Institute of SocialSciences

Zhuang, J. (2002). Whistle-blowing and peer reporting: a cross-cultural comparison of canadians and chinese. (Doktora Tezi). Alberta: Lethbridge University, Kanada.

\section{Copyrights}

Copyright for this article is retained by the author(s), with first publication rights granted to the journal.

This is an open-access article distributed under the terms and conditions of the Creative Commons Attribution license which permits unrestricted use, distribution, and reproduction in any medium, provided the original work is properly cited. 